\title{
COMMON FEATURES AND DISTINCTIONS BETWEEN HIGH TECHNOLOGY AND INNOVATION
}

\author{
Tetiana Serediuk', Yurii Vdovychenko²
}

\begin{abstract}
The goods, which are positioned on modern global markets as innovative and high-tech products, occupy more and more segments, owing to the contemporary modifications of the innovation diffusion theory and the ways of its implementation on high-tech markets. However, the meaning of the term "high technology" and "innovations" is quite disputable. An identification of the ontological characteristics of these definitions is of particular interest and practical value in terms of the transformation of a scientific and methodological framework for control of innovation diffusion in conditions of invariance on the market of high-tech information technology. Therefore, the author's article is aimed at the identification of the above-stated definitions and generalization of their distinctions. Methodology. The methodology of the article is based on the theoretical researches of Ukrainian and foreign scientists, which are synthesized, systematized, and analysed to identify the distinctive features of "high tech" and "innovations". One of the critical methodological tool, represented in the research, is an application of frequency analysis using online service "Google Books Ngram Viewer", which enabled us to compare frequency of references in scientific researches of the term "innovations" and "high technologies" as well as to compile analytical database of the research. Results. As a result of the author's study, it has been established that the frequency of using the term "innovations" is continuously increasing and the definition itself has a huge variety of interpretations. This paper suggests generalizing the innovations as the implementation of the new idea, which produces widespread and long-term changes. As distinct from innovations, a term "high technology" means the narrower spectrum of radical changes. Although it has a few names, such as "high-technology", "high tech", "high-tech", "hi-tech”, which, besides technology, can have other functionality. Practical implications. The presented results make it possible to develop more efficient communication channels for innovation diffusion, more precisely to identify innovators and mechanisms of their involvement in corporate activities, alternative forms of innovative activities in corporations. Value/originality. As a result of the study, it has been proved that technologies have common features with radical technical innovations, such as high science intensity, enhanced efficiency. Nevertheless, while being distributed on the market, innovation becomes a commodity and high technologies remain the same until the creation of state-of-the-art technologies. On this basis, it is possible more precisely to introduce innovations of IT companies according to information technology market segments.
\end{abstract}

Key words: global, markets, goods, modifications, theories, diffusion, innovations, high technologies, corporations.

JEL Classification: L00, N7, 014, 017, 03, Y30

\section{Introduction}

In conditions of modern dynamic economy and reduction in the duration of product cycles, a key to commercial success is an ability continuously and promptly to create new products and processes, driven by the development of new technologies.

The emergence of new technologies depends on the efficiency of researches. Thus, according to data of the WorldBank (2017), fortheperiodbetween 2000 and2014, a number of R\&D scientists has increased by 1.39 times (from 807 to 1127 scientists per a million of people), and a number of patent applications, submitted to the World Intellectual Property Organizations (WIPO), - by 2.08 times for residents and 1.77 times for non-residents (up to 1.7 and 0.8 millions of patent applications). The number of scientific and technical articles in journals has increased by 1.9 times (from 1.2 to 2.3 million articles) for the period between 2003 and 2016. At the same time, proceeds from intellectual property used for the same period has increased by 3.59 times (from 92,059 to 330,084 billion US Dollars), demonstrating an increase in the efficiency of researches.

\footnotetext{
Corresponding author:

${ }^{1}$ Non-Governmental Organization "Noosphere", Ukraine.

E-mail: tetiana.b.serediuk@gmail.com

${ }^{2}$ Cherkasy State Technological University, Ukraine.

E-mail: yurockv@gmail.com
} 
A final result of the research is to gain new knowledge that will become a foundation for high technologies and innovations. Cutting-edge technologies, which implement the innovative developments, are called high technologies. Creation of new high technologies is always based on innovations, which is the key driving force of economic development and is mainly a combination of the available production factors (Schumpeter, 2011). Sometimes high technologies and innovations are identified as the same ones.

The high technology world is characterized by an extremely high level of market and technological uncertainty (Moriarty \& Kosnik, 1989), and innovations in the high-tech sphere are not always welcomed by society. Thus, Dvorak keyboard, that has been developed for decades, despite its advantage over the standard QWERTY keyboard, is not so widespread (Rogers, 2010). At the same time, most of the available innovations have been developed as a response to discrete events, problematic stories and new technological opportunities (Taalbi, 2017).

Despite the fact that high technology sector is usually considered as a dynamic sector of the economy, since 2000 a very significant slowdown of entrepreneurial activities has been documented, primarily, in the USA (Haltiwanger, Hathaway \& Miranda, 2014).

It leaves relevant the issue of the study of high-tech market development and peculiarities of innovation diffusion in this market.

In modern global markets, the goods, which are positioned as innovative and high-tech products, occupy more and more segments owing to modern modifications of innovation diffusion theory and the ways of their implementation on high-tech markets. However, the meaning of the terms "high technologies" and "innovations" is still quite disputable. An identification of ontological characteristics of these categories is of considerable interest and practical value in terms of the transformation of a scientific and methodological framework for control of innovation diffusion in conditions of invariance on the market of information technologies. The current paper aims to demonstrate the terminological distinctions between high technology and innovation.

\section{Definition of high technology}

In the literature, the term "high technology" is close to the term "high-technology", "high tech", "high-tech", "hi-tech" (Figure 1).

Fig. 1 shows that in the second half of the 1980s of XX century the acronym "high-tech" became popular. The term "high-tech" was used as an acronym of high technology or an adjective that means using, requiring or involved in high technology: high-tech product, high-tech industry, high-tech cluster, high-tech sector. "Hi-tech" is often understood as architectural or designer style.

The term "high technology" is used to define technology. High technologies are characterized by the high degree of uncertainty in the achievement of a final result, uniqueness, prompt obsolescence, shortening of the life cycle - some of the high technologies are outdated at the stage of introduction into production (Skyba, 2014). A typical feature of high technology is high science intensity, high risks, and rapidity of changes in high-tech markets. Table 1 shows definitions of high technology by different authors.

Thus, high technology is a cutting edge technology, having a high knowledge intensity, which enhances the value of product or process for the consumer in the sense that the consumer obtains better quality, reduced costs or easier use of products in comparison with the outdated technology.

Modern high technologies are information technologies, programming, robotic technology, computing technology, aerospace technology, nanotechnologies, artificial intelligence, microelectronics, nuclear power engineering, biotechnologies, pharmaceutics, and gene engineering.

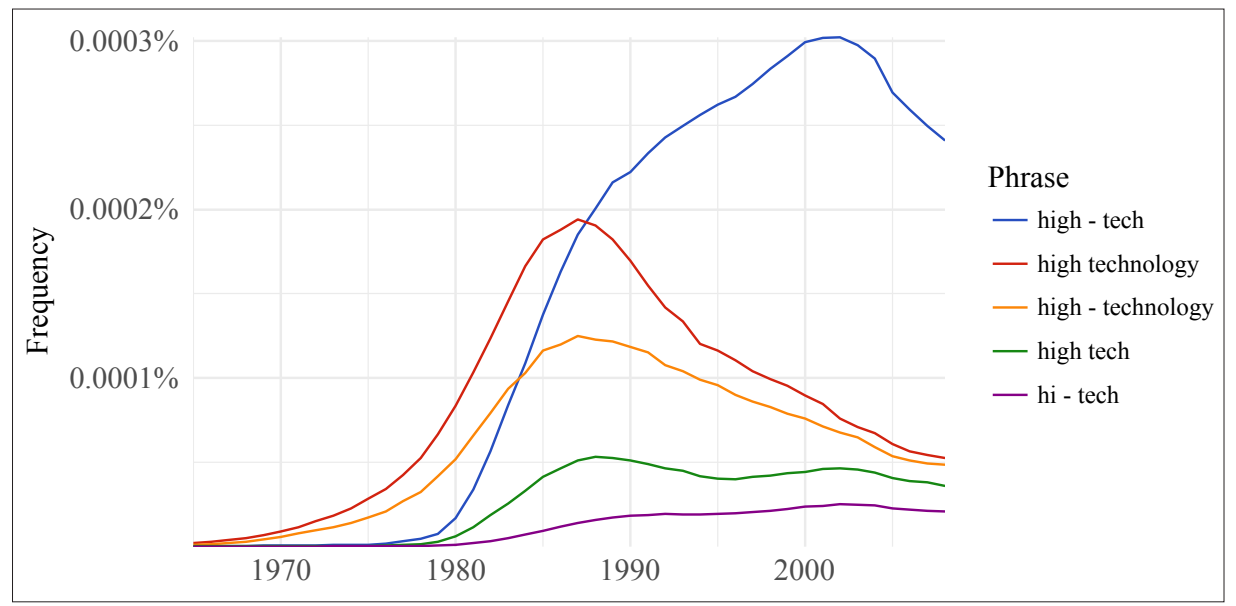

Figure 1. The frequency of n-grams "high technology" etc.

Source: data from Google Books Ngram Viewer (https://books.google.com/ngrams) 
Vol. 4, No. 5, 2018

Table 1

Definitions of high technology

\begin{tabular}{|c|l|}
\hline Author & \multicolumn{1}{c|}{ Definition } \\
\hline $\begin{array}{c}\text { Shanklin, Ryans \& Ryans } \\
(1987)\end{array}$ & $\begin{array}{l}\text { 1) an industry that has the double number of technical employees and doubles the R\&D outlays; } \\
\text { 2) technology that requires a strong scientific/technical basis; can obsolete existing technology rapidly; } \\
\text { as new technology comes on stream its applications create or revolutionize market and demands. }\end{array}$ \\
\hline Laliberté (2010) & $\begin{array}{l}\text { 1) any highly technical or specialized technological equipment or application; } \\
\text { 2) mostly used for technology involving complex electronics or software. }\end{array}$ \\
\hline Skyba (2014) & A synthesis of science, art and technological knowledge. \\
\hline Butko (2017) & $\begin{array}{l}\text { 1) technologies, based on systematized advanced knowledge, which can be materialized in certain products; } \\
\text { 2) ensure more efficient cost-benefit ratio in comparison with previous technologies, exceeding the performance } \\
\text { indicators of previous analogues or having no analogues in the past; } \\
\text { 3) trigger a chain reaction of innovations or initiate dynamic processes of sociocultural systems self-organizing. }\end{array}$ \\
\hline $\begin{array}{c}\text { Keeble, Wilkinson } \\
(2017)\end{array}$ & $\begin{array}{l}\text { 1) a catch-all phrase usually denoting industries producing technologically-advanced, sophisticated and } \\
\text { changing products; } \\
\text { 2) firms and industries whose products or services embody new, innovative and advanced technologies } \\
\text { developed by the application of scientific and technological expertise. }\end{array}$ \\
\hline
\end{tabular}

Source: formed by the authors

\section{Definition of innovation}

In the literature, the term "innovation" is used very often, even too often. For the last years, it has become just another buzzword (Shaver, 2014). According to the data of Google Books Ngram, a frequency of use of the term "high technology" is significantly lower than the use of the term "innovations" (Figure 2).

Table 2 shows definitions of the term "innovation" by different authors.

Thus, innovation is the implemented new ideas, which produce widespread or long-term changes. Creation and introduction of innovations is an efficient tool for enhancing efficiency and competitive advantage of individual enterprises, as well as the entire industries. In case of successful diffusion, the innovation becomes a commodity.

\section{Common features and distinctions}

A review of the recent literature indicates linkages between high technology and innovation. The majority of existing articles fail to provide clear distinctions between the features of high technology and innovation. Comparing the terms "high technologies" and "innovations" Butko (2017) defines the latter as a broader notion, which encompasses a wider spectrum of radical changes. A common feature of high technology and an innovation is that they must have been implemented.

In case of innovation, the level of maturity of products ultimately reduces the qualification requirements and it subsequently becomes a commodity: products become reliable, production processes - standardized, and price premium, obtained from the initial technological

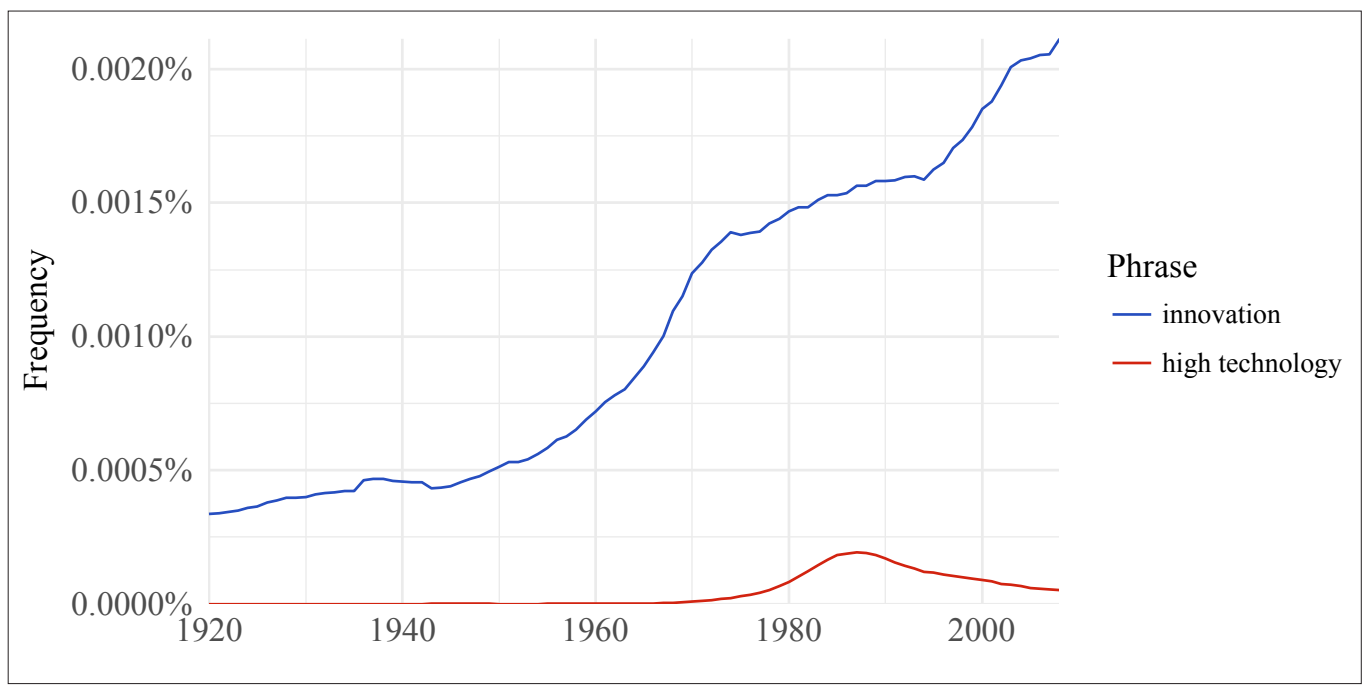

Figure 2. Comparison of frequency of n-grams "innovation" and "high technology"

Source: data from Google Books Ngram Viewer (https://books.google.com/ngrams) 
Table 2

Definitions of innovation

\begin{tabular}{|c|c|}
\hline Author & Definition \\
\hline $\begin{array}{c}\text { Dosi } \\
(1988)\end{array}$ & $\begin{array}{l}\text { The search for, and the discovery, experimentation, development, imitation, and adoption of new products, } \\
\text { new production processes, and new organizational set-ups. }\end{array}$ \\
\hline $\begin{array}{l}\text { West and Farr } \\
\qquad(1990)\end{array}$ & $\begin{array}{l}\text { Refers to the deliberate initiation and application within a firm of ideas, processes, products or procedures } \\
\text { which are new to the adopted unit and are created in order to benefit the firm or the wider society. }\end{array}$ \\
\hline OECD (2005) & $\begin{array}{l}\text { The implementation of a new or significantly improved product (good or service), or process, a new } \\
\text { marketing method, or a new organizational method in business practices, workplace organization or external } \\
\text { relations. }\end{array}$ \\
\hline $\begin{array}{l}\text { O’Sullivan \& Dooley } \\
\qquad(2009)\end{array}$ & $\begin{array}{l}\text { The process of making changes, large and small, radical and incremental, to products, processes, and services } \\
\text { that results in the introduction of something new for the organization that adds value to customers and } \\
\text { contributes to the knowledge store of the organization. }\end{array}$ \\
\hline $\begin{array}{l}\text { Christensen } \\
\quad(2013)\end{array}$ & $\begin{array}{l}\text { Refers to a change in one of the technologies, using which an organization transforms labour, capital, } \\
\text { materials, and information into products and services of greater value. }\end{array}$ \\
\hline Dos Santos Faria (2014) & Means technologies or practices that are new to a given society and they are not necessarily new in absolute terms. \\
\hline $\begin{array}{l}\text { McKinley, Latham, \& Braun } \\
\text { (2014) }\end{array}$ & $\begin{array}{l}\text { Any novel product, service, or production process that departs significantly from the prior product, service, } \\
\text { or production process architectures }\end{array}$ \\
\hline $\begin{array}{l}\text { Nahm } \\
(2014)\end{array}$ & $\begin{array}{l}\text { The process, used by firms to develop, master, and commercialize new product designs, services, and } \\
\text { production processes. Includes the process used to introduce new and improved technologies and practices } \\
\text { in commercial markets. }\end{array}$ \\
\hline Tidd and Bessant (2014) & Described as the process of creating value from ideas. \\
\hline Witzel (2014) & The process of introducing a new idea that creates a widespread or long-term change. \\
\hline $\begin{array}{l}\text { Mukhtar } \\
(2016)\end{array}$ & $\begin{array}{l}\text { In general, innovation can be considered as an interactive process to bring value into the market. In many } \\
\text { cases, the process is initiated by a technological breakthrough from research activity. This activity is followed } \\
\text { by other activities such as manufacturing and marketing. }\end{array}$ \\
\hline
\end{tabular}

Source: formed by the authors

advantage, is exhausted (Nahm, 2014). At the same time, science intensity of products reduces. In the case of hightech products, qualification requirements and science intensity are high during the whole product cycle.

Ding (2016) notes that $95 \%$ of innovations in the high-tech sector are seen in the technical areas. Oslo Manual highlights four types of innovations (OECD, 2005): product innovations, process innovations, organizational innovations and marketing innovations. High technologies are usually related to the first ones.

\section{Conclusions}

Therefore, based on the analysis of publicly available studies, it has been established that the frequency of using the term "innovations" is continuously increasing, and the term itself has a huge variety of interpretations. This paper suggests a generalized interpretation of the new idea, which produces widespread or long-term changes. As distinct from innovations, the term "high technology" means the narrower spectrum of radical changes, however, it has a few names, such as "hightechnology", "high tech", "high-tech", "hi-tech", which, besides technology, can have other functionality.
It can belong to high technology, architectural or designer style. Concerning the ontological characteristics, we suggest understanding is as cutting edge technologies, including the high level of knowledge intensity that enhances the value of product or process for the customer in the sense that such level ensures better quality, reduces costs or makes use of product easier in comparison with the outdated technology.

High technologies have common features with radical technical innovations, like high science intensity, increased productivity; although, in the result of market diffusion innovation becomes a commodity and high technologies remain the same before the creation of the new advanced technologies.

The results presented enable us to develop more efficient communication channels for innovation diffusion and more precisely to identify innovators and mechanisms of their involvement in corporate activities, alternative forms of innovative activities in corporations. On this basis, it is possible more precisely to introduce innovations of IT companies according to information technology market segments. Therefore, it is advantageous to study innovation diffusion in high-tech markets, taking into consideration the specifics of such innovations. 


\section{References:}

Butko, B. O. (2017). Vyznachennia ekonomichnoi katehorii vysokotekhnolohichnoho produktu v konteksti synerhetychnoi paradyhmy hlobalnoho rozvytku [High technology economical category within the context of synergetic paradigm of global development]. Naukovyi visnyk KhDU: Seriia "Ekonomichni nauky", 27, 22-25. Retrieved June 13, 2018, from: http://www.ej.kherson.ua/journal/economic_27/economic_27_1.pdf

Christensen, C. (2013). The innovator's dilemma: when new technologies cause great firms to fail. Harvard Business Review Press.

Ding, R. (2016). Innovation efficiency of high-tech industries in China (Doctoral dissertation, University of Nottingham).

Dos Santos Faria, P. I. (2014). The executive compensation: Pay-for-performance or innovation in high technology firms (Doctoral dissertation, Universidade do Porto (Portugal)).

Dosi, G. (1988). The nature of the innovative process. In G. Dosi, C. Freeman, R. Nelson, G. Silverberg, \& L. Soete (Eds.), Technical Change and Economic Theory. London, NY: Pinter Publishers.

Haltiwanger, J., Hathaway, I., Miranda, J. (2014). Declining business dynamism in the US high-technology sector. Ewing Marion Kauffman Foundation.

Keeble, D., Wilkinson, F. (2017). High-technology clusters, networking and collective learning in Europe. Routledge.

Laliberté, G. (2010). Innovation In High Technology (1/2). Retrieved June 5, 2018, from: https://www.slideshare.net/ slideshare_guy/innovation-in-high-technology-12

McKinley, W., Latham, S., Braun, M. (2014). Organizational decline and innovation: Turnarounds and downward spirals. Academy of Management Review, 39, 88-110.

Moriarty, R. T., Kosnik, T.J. (1989). High-tech marketing: concepts, continuity, and change. MIT Sloan Management Review, 30(4), 7.

Mukhtar, D. (2016). Implementation of technology driven policy initiatives in emerging economies: the case of Malaysia's Commercialization of Research and Development Fund (Doctoral dissertation, Nottingham Trent University).

Nahm, J. M. (2014). Varieties of Innovation: The Creation of Wind and Solar Industries in China, Germany, and the United States. Cambridge: Massachusetts Institute of Technology.

O’Sullivan, D., Dooley, L. (2009). Applying innovation. Thousand Oakes, CA: SAGE Publications.

OECD/Eurostat (2005). Oslo Manual: Guidelines for Collecting and Interpreting Innovation Data, 3rd Edition, The Measurement of Scientific and Technological Activities, OECD Publishing, Paris. Retrieved from: http://dx.doi.org/10.1787/9789264013100-en

Rogers, E. M. (2010). Diffusion of innovations. Simon and Schuster.

Schumpeter, J. (2011). Theory of Economic Development: An Inquiry into Profits, Capital, Credit, Interest, and the Business Cycle. Ukrainian translation by V. Starko. Kyiv, Publishing House of "Kyiv-Mohyla Academy". (in Ukrainian)

Shanklin, W. L., Ryans, J. K., Ryans, J. C. (1987). Essentials of marketing high technology. Lexington Books.

Shaver, E. F. (2014). The many definitions of innovation. Retrieved June 12, 2018, from: http://www.ericshaver.com/ the-many-definitions-of-innovation/

Skyba, I. P. (2014). Instrumentalne znannia i vysoki tekhnolohii [Instrumental knowledge and high technologies.]. Naukovi zapysky KUTEP, 282-293. Retrieved June 13, 2018, from: http://er.nau.edu.ua:8080/handle/ NAU/18372

Taalbi, J. (2017). What drives innovation? Evidence from economic history. Research Policy, 46(8), 1437-1453. Retrieved from: http://dx.doi.org/10.1016/j.respol.2017.06.007

Tidd, J., Bessant, J. (2014). Strategic innovation management. John Wiley \& Sons.

West, M. A., Farr, J. L. (1990). Innovation at work. Innovation and creativity at work: Psychological and organizational strategies. Chichester: Wiley.

Witzel, E. W. (2014). Wheel of innovation: How leaders' attitudes and behaviors drive disruptive technology in the US Navy. Andrews University.

World Bank. International Economics Dept. Development Data Group (2017). World development indicators. World bank. Retrieved June 13, 2018, from: http://databank.worldbank.org/data/download/WDI_excel.zip 